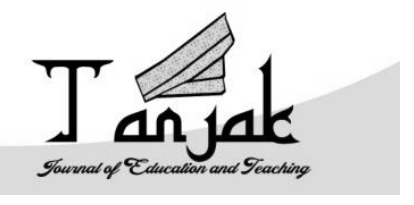

Tanjak: Journal of Education and Teaching

ISSN 2716-4098 (P) 2720-8966 (O)

Volume 2 Nomor 1, 2021

\title{
PENINGKATAN PEMAHAMAN TAJWID SISWA KELAS VIII 4 MELALUI STRATEGI COOPERATIF LEARNING DI TPQ SMPN 13 BINTAN
}

\section{Zulkifli}

SMPN 13, Bintan, Kepulauan Riau, 29152, Indonesia

DOI: https://doi.org/10.31629/ig.v2i1.243

\begin{abstract}
Abstrak
Metode memiliki kedudukan yang sangat signifikan dalam mencapai tujuan pendidikan Islam. Keberhasilan pembelajaran tergantung bagaimana penerapan metode yang tepat dalam proses pembelajaran. Sebaliknya, metode yang kurang tepat akan mengakibatkan kegagalan dalam mencapai tujuan pembelajaran. Berdasarkan pengamatan yang dilakukan oleh peneliti pada hasil belajar mata pelajaran tajwid siswa kelas 8 SMP Negeri 13 Bintan menunjukkan sebanyak 50\% siswa mendapatkan nilai di bawah Kriteria Ketuntasan Minimal (KKM). Untuk mengatasi masalah tersebut, guru menerapkan teknik Cooperative Learning pada mata pelajaran tajwid untuk meningkatkan hasil belajar siswa. Teknik Cooperative Learning memiliki dua proses tahapan, yaitu: berdiskusi dan kerja kelompok. Penerapan teknik ini dilakukan dengan dua siklus dimana masing-masing siklus memiliki dua tahapan, tahap pertama: siswa melakukan diskusi terkait materi yang diberikan. Sedangkan tahap kedua, siswa melakukan kerja kelompok berdasarkan tugas yang diberikan oleh guru. Hasil penerapan Teknik Cooperating Learning menunjukkan bahwa ada peningkatan hasil belajar siswa dalam menguasai materi secara konsep sebesar 20,46\% dan penerapan materi tajwid sebanyak 13,63\%. Teknik ini terbukti mampu meningkatkan antusias siswa dalam proses pembelajaran pada materi tajwid sebesar 100\%. Berdasarkan hasil pengamatan menunjukkan bahwa dalam menerapkan Teknik Cooperating Learning dalam pembelajaran siswa menunjukkan motivasi yang tinggi dan meningkatnya kemampuan siswa dalam mengungkapkan hasil belajar secara verbal serta dalam berfikir kritis menjadi hidup sehingga siswa menjadi termotivasi Teknik "Cooperative Learnig" juga membawa manfaat positif terhadap kemampuan siswa mengungkapkan hasil pembelajaran melalui kata- kata dan berfikir kritis
\end{abstract}

Kata kunci: Tajwid. Cooperative Learning. diskusi

Tanjak: Jounal of Education and Teaching, Vol. 2, No. 1, 2021 


\begin{abstract}
The method has a very significant position in achieving the goals of Islamic education, therefore, the application of the right method greatly influences the success in the teaching and learning process. On the other hand, errors in implementing the method will be fatal. In the tajwid material, student learning outcomes at SMPN 13 Bintan are classified as low. This can be seen from the results of the assessment carried out by the teacher during grade VIII which stated that students who scored below the Minimum Completeness Criteria) were more than 50\%. To solve this problem, try to find a solution to improve the learning outcomes of tajwid material by using the "COOPERATIVE LEARNING" technique, which is a learning technique that uses three stages of the process, namely, discussion and group work. The research implementation process was carried out for two cycles. Cycles 1 and 2, each cycle consisting of 2 meetings. Meeting 1 carried out the "Discuss" stage, while meeting 2 conducted the "Group work" stage. The technique of "COOPERATIVE LEARNING" has been proven to improve student learning outcomes of $20.46 \%$ mastery of concepts and $13.63 \%$ application. $100 \%$ of students stated that the technique was. fun and able to make the classroom atmosphere come alive so that students become motivated. "Cooperative Learning" technique also brings positive benefits to students' ability to express learning outcomes through words and critical thinking
\end{abstract}

Keywords: Tajwid. Cooperative Learning. discussion

\title{
Pendahuluan
}

Bidang pendidikan dituntut untuk selalu berkembang dan adaptif terhadap perubahanperubahan yang dialami oleh sebagian besar bangsa-bangsa di dunia ini khususnya bangsa Indonesia. Gaya mendidik yang konvensional atau tradisional sudah tidak relevan lagi mengingat prosedur dan pencapaian terget yang tidak efektif dan efisien. Pemerintah melalui kebijakan-kebijakan yang diterapkan telah berupaya untuk meningkatkan mutu pendidikan dari segala sisi, antara lain: penyempurnaan kurikulum, peningkatan kualitas guru, perbaikan proses pembelajaran, dan pengadaan sarana dan prasarana.

Melalui kurikulum tahun 13 (K-13) pemerintah berupaya untuk meningkatkan dan memperbaiki mutu pendidikan dengan memantapkan proses pembelajaran dan materi ajarnya yang beroreantasi kepada pengembangan potensi diri untuk memilki kekuatan spritual keagamaan, pengendalian diri, kecerdasan, keperibadian, akhlak mulia serta keterampilan yang berguna untuk dirinya dan masyarakat. ${ }^{1}$ Oleh sebab itu, guru Pendidikan Agama Islam (PAI) memiliki peran penting agar Agama Islam sebagai agama maupun mata pelajaran dijadikan sebagai landasan pengembangan spiritual siswa sehingga mewujudkan kehidupan masyarakat yang lebih baik.

Melalui pengamatan yang dilakukan peneliti pada materi Pendidikan Agama Islam (PAI), memperoleh beberapa fakta lapangan yang dapat dijadikan sebagai masalah untuk melakukan kegiatan penelitian tindakan kelas (PTK). Beberapa masalah yang didapat adalah rendahnya motivasi siswa dalam belajar, kurangnya aktifitas siswa selama proses pembelajaran, dan daya tangkap siswa yang terhadap materi pelajaran yang lambat. Kondisi demikian membutuhkan keterampilan guru dalam menerapkan metode pembelajaran yang tepat dan sesuai agar tujuan pembelajaran tercapai. Oleh karena itu, penting sekali bagi guru Pendidikan Agama Islam menerapkan metode dan strategi pembelajaran yang kreatif dan inovatif supaya di dalam pembelajaran muncul umpan balik yang positif dari siswa yang akan meningkatkan minat dan rasa ingin tahu yang tinggi terhadap mata pelajaran Pendidikan Agama Islam.

\footnotetext{
${ }^{1}$ Lihat: Permendikbud No. 23 Th.2016.
}

Tanjak: Jounal of Education and Teaching, Vol. 2, No. 1, 2021 
Para siswa akan mendapatkan pengalaman belajar jika berpartisipasi langsung dalam proses pembelajaran. Guru hendaknya menerapkan metode dan strategi belajar dalam proses mengajar disesuaikan dengan karakteristik materi yang akan diajarkan sehingga siswa mendapat pengalaman belajar yang baru. Metode dan strategi belajar hendaknya melibatkan partisipasi siswa langsung agar memiliki pengaruh yang signifikan terhadap kemampuan siswa dalam menyerap informasi-inforamsi baru dari materi ajar yang disampaikan guru. Pendekatan yang digunakan guru harus lebih bervariasi baik itu yang berkaitan dengan proses penyampaian materi ajar atau motivasi guru melalui pemberian hadiah, pujian, atau sejenisnya agar siswa terdorong untuk lebih aktif dalam belajar.

Berdasarkan observasi awal, peneliti mendapatkan data bahwa siswa kelas 8 SMPN 13 Bintan memiliki pemahaman yang rendah. Hal ini dibuktikan dengan data angket yang disebar sebagai observasi awal kepada 27 siswa pada pelajaran PAI materi tajwid, sebanyak 15\% menyatakan senang, 55\% menyatakan kurang senang, dan 30\% lainnya menyatakan tidak senang. Rendahnya minat siswa terhadap materi tajwid mengindikasikan bahwa metode yang digunakan oleh guru tidak merangsang motivasi siswa untuk belajar yang berakibat pada rendahnya nilai yang diperoleh siswa. Padahal, pelajaran tajwid merupakan materi yang harus dikuasai oleh siswa mengingat ilmu ini adalah ilmu dasar membacar al Quran agar baik dan benar.

Melalui Teknik Cooperating Learning guru berusaha untuk meningkatkan pemahaman siswa kelas 8 SMPN 13 Bintan pada materi tajwid dan menjadikan teknik ini sebagai bahan penelitian Tindakan kelas. Penelitian ini penting dilakukan mengingat tren mata pelajaran PAI terutama pada bab tajwid mengalami penurunan pada nilai-nilai siswa SMPN 13 Bintan dan banyak yang tidak mencapai nilai KKM.

\section{Metode Penelitian}

Tempat penelitian dilaksanakan di SMP Negeri 13 Bintan, Jln Taman Sari Tanjung uban Kec. Bintan utara Kab. Bintan Prov. Kepulauan Riau. Subjek penelitian adalah siswa kelas VIII 4 SMP Negeri 13 Bintan tahun pelajaran 2019/2020 yang jumlahnya 27 orang. Penelitian dilaksanakan selama 2 bulan yakni tanggal 15 September 2019 - 15 November 2019 pada Semester Ganjil Th. Pelajaran 2019/2020. Penulis dibantu 2 orang guru, yaitu: Mu'arifin, S.Pd.I., teman sesama guru mata pelajaran PAI dan sebagai sebagai kolaborator; dan Sujoko, M.Pd., yang membantu perekaman selama proses penelitian.

Penelitian ini dilaksanakan dalam 2 siklus dimana masing-masing siklus terdiri dari 2 kali pertemuan. Kegiatan pelaksanaan tindakan kelas dapat digambarkan sebagai berikut:

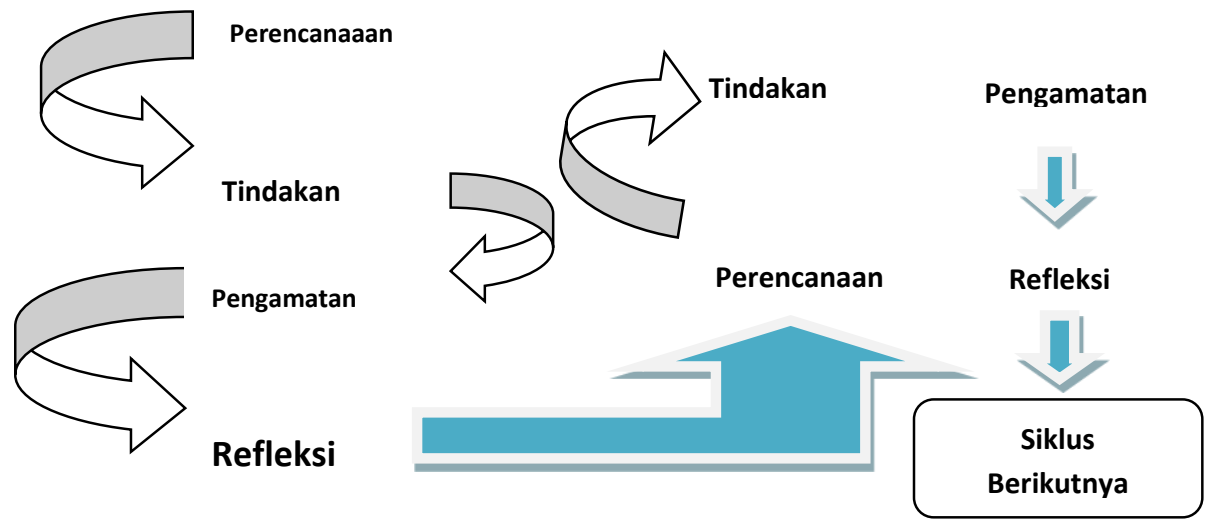

Gambar 1. Siklus Kegiatan Pelaksanaan Penelitian Tindakan Kelas

Tanjak: Jounal of Education and Teaching, Vol. 2, No. 1, 2021 
Teknik analisis data yang terkumpul berupa data kuantitatif (nilai hasil belajar siswa) yang dianalisis secara deskriptif. Dalam hal ini peneliti menggunakan analisis statistik deskriftif dengan mencari mencari nilai rerata; (persentase keberhasilan belajar; dan menganalisis hasil angket siswa serta diakhiri dengan suatu kesimpulan dari hasil analisis data tersebut. Teknik analisis data kuantitatif deskriptif, yaitu peneliti

Adapun indikator keberhasilan mata pelajaran PAI pada penelitian ini adalah:

Tingkat kemampuan siswa pada materi tajwid mata pelajaran PAI secara individual yang bersifat evaluatif adalah sekurang-kurangnya mendapatkan nilai 75 untuk aspek penguasaan konsep dan ketuntasan klasikal mencapai $85 \%$.

Tingkat penerapan siswa terhadap materi tajwid dalam membaca alqur'an yang dinilai dengan menggunakan teknik unjuk kerja sekurang-kurangnya 75\% dan ketuntasan klasikal mencapai 85\%.

\section{Hasil dan Pembahasan}

Sebenarnya, pembelajaran Pendidikan Agama Islam tidak hanya menekankan pada penguasaan konsep dan nilai- nilai. Yang lebih penting dari itu adalah penerapan nilai- nilai dalam kehidupan seharihari sehingga Pelajaran PAI baru dikatakan berhasil apabila terjadi perubahan sikap pada diri peserta didik yang didasari dari kesadaran diri yang tinggi. Dengan adanya perubahan sikap pada peserta didik, diharapkan akan semakin meningkatkan keimanan dan ketaqwaan peserta didik kepada Tuhan Yang Maha Esa. Tujuan pengajaran Agama Islam menurut Dr. Zakiyah Daradjat adalah supaya orang mempunyai pengetahuan tentang ajaran Islam untuk diyakini dan diamalkan sehingga ia menjadi seorang muslim dan selanjutnya berkepribadian muslim. Hal ini sejalan dengan tujuan pendidikan Nasional yang akan membentuk manusia Pancasilais yang bertakwa kepada Tuhan Yang Maha Esa.

Apakah pembelajaran PAI selama ini sudah memenuhi harapan tersebut? Sebuah fakta yang tidak bisa dipungkiri bahwa selama ini, peserta didik menganggap bahwa pelajaran PAI merupakan pelajaran yang tidak menarik dan membosankan. Hal itu mungkin dikarenakan materi PAI kebanyakan berupa nilai, moral dan norma-norma yang bersifat abstrak dan dogmatis. Esensi dari materi PAI tersebut mengakibatkan guru PAI merasa bahwa metode penyampaian yang paling tepat untuk pelajaran PAI adalah metode ceramah.

Kenyataan diatas merupakan sebuah tantangan dari guru PAI untuk bisa menampilkan Pelajaran PAI sebagai sebuah pembelajaran yang menarik dan menyenangkan agar tujuan pengajaran Agama Islam dapat tercapai. Karena, bagaimana mungkin nilai- nilai yang terkandung dalam PAI tersebut akan diamalkan apabila pelajaran itu sendiri dianggap tidak menyenangkan dan membosankan oleh peserta didik?

Penggunaan metode yang tepat akan turut menentukan efektifitas dan efisiensi pembelajaran. Penggunaan metode yang bervariasi akan sangat membantu peserta didik dalam mencapai tujuan pembelajaran. Pengalaman belajar di sekolah harus fleksibel dan tidak kaku, serta perlu menekankan ada kreatifitas, rasa ingin tahu, bimbingan dan pengarahan ke arah kedewasaan. Dr.E.Mulyasa mengatakan bahwa kreatifitas peserta didik sangat tergantung pada kreatifitas guru dalam mengembangkan materi stándar, dan menciptakan lingkungan belajar yang kondusif. Guru dapat mengadakan berbagai pendekatan dalam meningkatkan kreatifitas peserta didik.

Dari hasil observasi dan perolehan angket yang penulis sebar, dapat ditarik kesimpulan bahwa siswa kelas VIII 4 di SMP Negeri 13 Bintan membutuhkan strategi pembelajaran yang lebih tepat untuk

Tanjak: Jounal of Education and Teaching, Vol. 2, No. 1, 2021 
memahami materi tajwid agar dapat meningkatkan hasil belajar siswa. Dalam melakukan proses belajar mengajar, guru harus menggunakan metode yang bervariasi dan tidak monoton dengan menggunakan satu metode saja. Dengan menggunakan metode yang bervariasi, siswa akan merasa termotivasi dan senang mengikuti kegiatan pembelajaran. Disamping itu, metode yang digunakan juga harus dapat meningkatkan keaktifan siswa di kelas.

"Strategi pembelajaran cooperatif learning" diterapkan oleh peneliti dengan sebuah pendekatan yang tidak membatasi ruang gerak peserta didik dalam pembelajaran dan mengembangkan kreatifitas peserta didik untuk mendapatkan pengetahuan- pengetahuan baru. Teknik ini juga membantu mengembangkan rasa percaya diri peserta didik dengan membantu mereka mengembangkan kesadaran dirinya secara positif tanpa menggurui dan mendikte mereka. Setelah penulis laksanakan teknik ini dalam materi tajwid selama dua siklus, penulis dapat menyimpulkan bahwa penting sekali bagi guru untuk mengetahui kecenderungan gaya belajar siswa. Dengan mengetahui kecenderungan gaya belajar, guru akan dapat menentukan metode dan media apa yang tepat digunakan dalam proses pembelajaran sesuai dengan karakteristik materi pelajaran. Apabila metode dan media pembelajaran sudah tepat, maka siswa akan lebih mudah dan cepat menyerap sebuah informasi.

Model Pembejaran "Cooperativ learnig" terbukti bisa menfasilitasi siswa pebelajar dengan gaya belajar yang berbeda (visual, auditorial dan kinestetik). Tahapan-tahapan pada Cooperativ Learning" juga memberikan kesempatan kepada siswa untuk berkembang sesuai dengan kecerdasan berganda yang dimiliki oleh masing- masing siswa. Merubah paradigma belajar yang selama ini berakar pada diri siswa, dari paradigma duduk dan dengar menjadi paradigma lakukan, berfikir dan katakan.

\section{Strategi Pembelajaran “Cooperatif Learning” dengan Kemampuan Penguasaan Konsep}

Hasil perbandingan penerapan teknik cooperatif learning pada pembelajaran materi tajwid setelah dan sebelum diterapkan dapat dilihat pada tabel berikut ini:

Tabel 1.

Perubahan Kemampuan Penguasaan Konsep

\begin{tabular}{|l|l|l|l|}
\hline Siklus & \% Pre Test & \% Post Test & Perubahan \\
\hline Pertama & 51,85 & 66,67 & naik 14,82 \\
\hline Kedua & 75,81 & 85,18 & Naik 9,37 \\
\hline
\end{tabular}

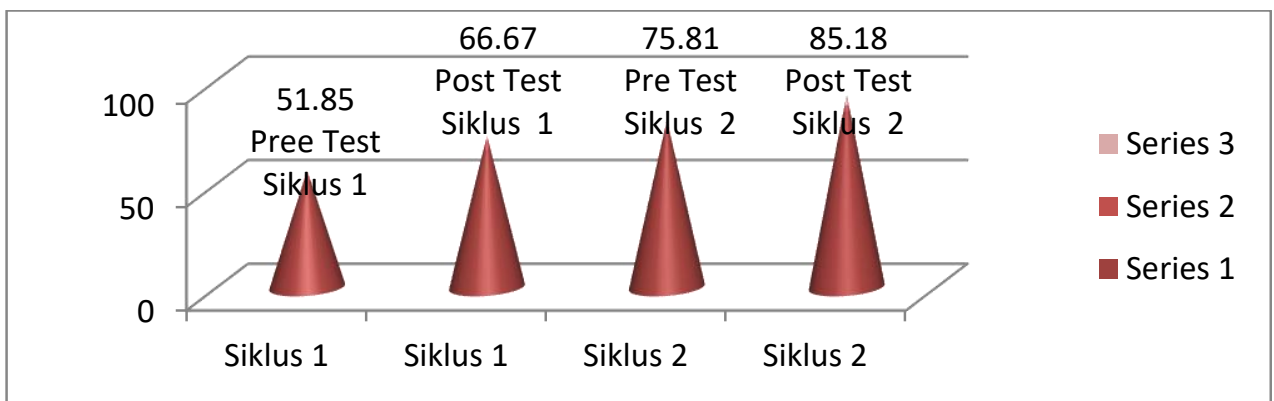

Gambar 2. Kemampuan Penguasaan Konsep

Dari tabel dan grafik diatas dapat diketahui bahwa penggunaan Model Pembelajaran "Cooperatif Learning" membawa peningkatan hasil belajar pada aspek penguasaan konsep dan nilai- nilai. Pada siklus pertama terjadi kenaikan 33,34\% dari pre-test, sedangkan pada siklus kedua terjadi kenaikan 18,51 \% dari

Tanjak: Jounal of Education and Teaching, Vol. 2, No. 1, 2021 
pre-test siklus kedua. Taraf keberhasilan hasil belajar siswa pada siklus pertama adalah 66,67 \%, sedangkan ada siklus kedua taraf keberhasilannya adalah 85,18\% dengan kategori baik. Dengan demikian terjadi peningkatan taraf keberhasilan hasil belajar pada aspek penguasaan konsep dan nilai- nilai siswa pada siklus pertama ke siklus kedua yaitu sebesar 18,51 \%. Strategi Pembelajaran "Cooperatif Learning" bisa menfasilitasi siswa untuk belajar dengan perbedaan modalitas belajar yang dimiliki oleh siswa (visual, auditorial dan kinestetik). Tahapan- tahapan pada "Cooperatif Learning" memberikan pengalaman belajar yang beragam pada siswa dengan melibatkan modalitas belajar yang dimilikinya. Hal ini menyebabkan siswa lebih memperhatikan materi pelajaran dan lebih mudah menguasai materi yang diajarkan oleh guru tanpa harus didikte oleh guru.

\section{Strategi Pembelajaran “Cooperatif Learning” dengan Hasil Belajar Aspek Penerapan}

Hasil nilai pre-test dan post-test siswa kelas 8 SMP Negeri 13 Bintan setelah diterapkan teknik cooperatif learning, ditampilkan pada tabel berikut:

Tabel 2. Perubahan Kemampuan Aspek Penerapan

\begin{tabular}{|l|l|l|l|}
\hline Siklus & \% Pre Test & \% Post Test & Perubahan \\
\hline Pertama & 70,37 & 81,84 & naik 11,47 \\
\hline Kedua & 74,07 & 88,88 & naik 14,81 \\
\hline
\end{tabular}

\begin{tabular}{|cccccc|}
\hline & 81.84 & 74.07 & 88.88 \\
\hline
\end{tabular}

Gambar 3. Hasil Belajar Aspek Penerapan

Dari tabel dan grafik tersebut diatas dapat diketahui bahwa penggunaan Model Pembelajara "Cooperati Learning" membawa peningkatan hasil belajar pada aspek penerapan. Pada siklus pertama terjadi kenaikan 11,47 \% dari pre-test, sedangkan pada siklus kedua terjadi kenaikan 14,81\% dari postest siklus kedua. Taraf keberhasilan hasil belajar siswa pada siklus pertama adalah $72,73 \%$, sedangkan pada siklus kedua taraf keberhasilannya adalah 86,36 \% dengan kategori baik. Dengan demikian terjadi peningkatan taraf keberhasilan hasil belajar pada aspek penguasaan konsep dan nilai- nilai siswa pada siklus pertama ke siklus kedua yaitu sebesar 13,63\%.

Materi tajwid merupakan materi yang digunakan dalam membaca Al Qur'an sehingga orang Islam dapat membacanya dengan baik dan benar. Oleh karena itu, penerapan ilmu tajwid dalam membaca Al Qur'an penting sekali untuk diperhatikan oleh guru. Mengajar materi tajwid tidak hanya terbatas pada usaha transfer of knowledge saja, namun juga harus diiringi dengan usaha transfer of actifity. Transfer of actifity disini bisa berupa pembiasaan membaca $\mathrm{Al}$ Qur'an baik di kelas maupun di rumah atau memotivasi siswa

Tanjak: Jounal of Education and Teaching, Vol. 2, No. 1, 2021 
sehingga menjadi senang membaca Al Qur'an dengan menghadirkan cerita-cerita Islami dalam pembelajaran. Dengan upaya transfer of actifity dalam pembelajaran tajwid, diharapkan siswa lebih mencintai $\mathrm{Al}$ Qur'an serta timbul kesadaran untuk membaca dan mengamalkan dalam kehidupan sehari- hari.

\section{Model Pembelajaran "Cooperativ Learning" dengan Perubahan Sikap}

Belajar merupakan perubahan perilaku seseorang melalui latihan dan pengalaman, motivasi akan memberi hasil yang lebih baik terhadap perbuatan yang dilakukan seseorang. Hasil belajar dapat diukur dalam bentuk perubahan pengetahuan, sikap da ketrampilan, perubahan yang lebih baik dari sebelumnya, misalnya dari tidak bisa menjadi bisa, dan dari tidak santun menjadi santun ${ }^{2}$ Motivasi merupakan salah satu faktor yang dapat meningkatkan kualitas pembelajaran, karena peserta didik akan belajar dengan sungguh- sungguh apabila memiliki motivasi yang tinggi. Menurut Howard, setiap guru sebaiknya memiliki rasa ingin tahu, mengapa dan bagaimana anak belajar dan menyesuaikan dirinya dengan kondisi belajar dalam lingkungannya. Motivasi tidak muncul begitu saja pada diri siswa, perlu ada stimulus atau dimunculkan. Untuk pelajaran PAI lebih sulit memunculkan motivasi siswa karena kebutuhan akan pelajaran PAI tidak bisa dirasakan siswa dalam waktu dekat. Kalau PAI menjadi salah satu mapel UN, kemungkinan memunculkan motivasi akan lebih mudah. Oleh karena itu, pemilihan metode yang menyenangkan dan tidak membosankan akan membantu memunculkan motivasi siswa.

Model Pembelajaran "Cooperativ Learning" yang penulis pakai sangat memungkinkan untuk mengembangkan minat dan motivasi siswa. Terbukti dari sikap antusiame siswa dalam proses belajar mengajar. Berikut ini penulis paparkan hasil angket siswa setelah mengikuti proses belajar mengajar menggunakan Model Pembelajaran "Cooperativ Learning"

Tabel 3. Hasil Angket Siswa tentang Penerapan Model Pembelajaran "Cooperativ Learning”

\begin{tabular}{|c|l|c|c|}
\hline \multirow{2}{*}{ No } & \multicolumn{1}{|c|}{ Instrumen } & \multicolumn{2}{|c|}{ Persentase } \\
\cline { 2 - 4 } & \multicolumn{1}{|c|}{ Ya } & Tidak \\
\hline 1 & $\begin{array}{l}\text { Apakah pembelajaran dengan menggunakan Model Pembelajaran } \\
\text { "Cooperativ Learning" itu menyenangkan? }\end{array}$ & $100 \%$ & - \\
\hline 2 & $\begin{array}{l}\text { Apakah Model Pembelajaran "Cooperativ Learning” memudahkan } \\
\text { dalam memahami materi pelajaran? }\end{array}$ & $97,5 \%$ & $2,5 \%$ \\
\hline 3 & $\begin{array}{l}\text { Apakah Model Pembelajaran "Cooperativ Learning” menumbuhkan } \\
\text { motivasi belajar pada kamu? }\end{array}$ & $100 \%$ & - \\
\hline 4 & $\begin{array}{l}\text { Apakah Model Pembelajaran "Cooperativ Learning” dapat mengatasi } \\
\text { kesulitan belajar yang pernah dirasakan selama ini ? }\end{array}$ & $97,5 \%$ & $2,5 \%$ \\
\hline 5 & $\begin{array}{l}\text { Apakah Model Pembelajaran "Cooperativ Learning” membuat nilai } \\
\text { ulangan meningkat? }\end{array}$ & $87,5 \%$ & $12,5 \%$ \\
\hline 6 & $\begin{array}{l}\text { Apakah Model Pembelajaran "Cooperativ Learning” perlu terus } \\
\text { diterapkan? }\end{array}$ & $90 \%$ & $10 \%$ \\
\hline
\end{tabular}

Dari pengamatan penulis, Model Pembelajaran "Cooperativ Learning" juga menumbuhkan keberanian memberikan tanggapan pada komentar yang diberikan oleh temannya pada saat berdiskusi.Hal ini memberi motivasi kepada siswa untuk berani mengemukakan komentar karena pada tahap itu masingmasing anak dituntut untuk berani mengemukakan konsep yang sudah didapat atau pendapatnya. Model Pembelajaran "Cooperativ Learning" juga bermanfaat dalam membantu pembentukan karakter siswa dan

${ }^{2}$ Martinis Yamin, Profesionalisasi Guru dan Implementasi KTSP. (Gaung: Persada Perss, 2007), 18. Tanjak: Jounal of Education and Teaching, Vol. 2, No. 1, 2021 
melatih kepekaan sosial siswa. Dalam permainan dan berdiskusi, mereka belajar berinteraksi dengan orang lain, belajar memperhatikan pendapat teman serta memberikan komentar- komentar yang bermanfaat. Proses belajar seperti ini akan sangat membantu melatih rasa sosial siswa serta kepedulian terhadap orang yang ada di sekitarnya.

Kenyataan diatas sesuai dengan harapan bahwa mata pelajaran yang diajarkan di sekolah, terutama mata pelajaran PAI hendaknya dapat menyentuh hati siswa serta bisa melahirkan sikap positif pada siswa (transfer of value) sehingga akan menumbuhkan rasa cinta terhadap kebenaran dan membenci kejahatan. Dengan demikian, mereka tidak hanya menjadi generasi muda yang pintar saja, akan tetapi juga berkarakter dan berakhlakul karimah.

\section{Kesimpulan}

Hasil penelitian tindakan kelas menunjukkan adanya perubahan signifikan aktifitas belajar siswa yang mengalami peningkatan. Selama pembelajaran menggunakan metode cooperative learning motivasi siswa terlihat meningkat, kemampuan memahami materi lebih cepat, dan sikap kritis siswa mengalami perubahan. Dengan demikian teknik cooperative learning dapat diterapkan dalam pembelajaran PAI pada materi tajwid.

\section{Ucapan Terimakasih}

Terimakasih kami ucapkan kepada rekan satu tim, Bpk Mu'arifin dan Sujoko, atas bantuannya sehingga penyusunan PTK ini selesai sesuai dengan jadwal. Semoga artikel ini dapat bermanfaat bagi para praktisi pendidikan khususnya para guru PAI dan bisa menjadi refrensi dalam mencari metode pengajaran yang baik.

\section{Referensi}

Arikunto, Suharsimi. 2002. Penelitian Tindakan Kelas. Jakarta: Bumi Aksara.

Arsyad,Azhar.1997. Media Pembelajaran. Jakarta : Raja Grafindo Perkasa.

Daradjat, Zakiyah. 1983.Metodologi Pengajaran Agama Islam. Jakarta : Bumi Aksara.

Depdiknas. 2008. Strategi Pembelajaran dan Pemilihannya.Direktorat Jendral Peningkatan Mutu Pendidikan dan Tenaga Kependidikan, Departemen Pendidikan Nasional.

Deporter, Bobbi,dkk. 2000. Quantum Teaching Memraktekkean Quantum Learning di Ruang- ruang Kelas. Bandung: Mizan Media Utama.

Ghony, M. Djunaidi. 2008. Penelitian Tindakan Kelas. Malang : UIN Perss.

Muhaimin dan Abdul Mujib. 1993. Pemikiran Pendidikan Islam. Jakarta: Tri Genda Karya.

Mulyasa. E, 2005. Menjadi Guru Profesional. Bandung : Remaja Rosdakarya.

Muslih, Masnur. 2007. KTSP Pembelajaran Berbasis Kompetensi dan Kontekstual. Jakarta : Bumi Aksara.

Nasution, S. 1982. Berbagai Pendekatan dalam Proses Belajar dan Mengajar. Jakarta : Bumi Aksara.

Tanjak: Jounal of Education and Teaching, Vol. 2, No. 1, 2021

http://ejournal.stainkepri.ac.id/index.php/tanjak 
dan Thomas.2002. Buku Penuntun Membuat Tesisi, Skripsi, Disertasi dan Makalah. Jakarta : Bumi Aksara.

Sanjaya, Wina. 2008. Kurikulum dan Pembelajaran. Jakarta Kencana Predana Media Group.

Sukmadinata, Nana Syaodih. 2005 Metode Penelitian Pendidikan. Bandung : Remaja Rosdakarya.

Uno, Hamza B. 2007. Model Pembelajaran, Menciptakan Pembelajaran yang Kreatif dan Efektif. Jakarta : Bumi Aksara.

Yamin, Martinis. 2007. Profesionalisasi Guru dan Implementasi KTSP. Gaung Persada Perss.

Http://nesaci.com/metode-diskusi-dalam-proses-belajar-di-sekolah.

Http://www.alquran-sunnah.com/alquran/ilmu-tajwid.html. 